\title{
Comparative analysis of public transport modes available in Karachi, Pakistan
}

\author{
Syed Muhammad Noman ${ }^{1} \cdot$ Afzal Ahmed $^{2}$ (D) Mir Shabbar Ali ${ }^{2}$
}

Received: 12 November 2019 / Accepted: 2 April 2020 / Published online: 25 April 2020

(c) Springer Nature Switzerland AG 2020

\begin{abstract}
This study presents a comparative analysis of selected parameters of existing formal and informal Public Transport (PT) modes being operated on three different types of fuels. The performance of PT modes is analysed on fuel consumption, capacity, transportation cost, and emissions resulting from these modes. The required data were collected using route-check survey method and conducting a questionnaire-based survey from drivers and operators of these modes. Furthermore, the performance of proposed buses for an under-construction BRT corridor is also evaluated and compared with the existing PT modes. The comparative analysis of the existing PT modes in Karachi shows that CNG operated PT modes are economically more efficient, which caused the conversion of diesel engines of buses and minibuses to CNG fuelled-engines. The study, for the first time, evaluates and compares the performance of informal PT mode (chingchi) with other modes of PT. Results show that the PT modes with less capacity, such as chingchi, should be discouraged due to their comparatively lower performance on the selected parameters. This study can be used by the authorities to analyze the performance of existing modes and prioritize the PT modes for future planning.
\end{abstract}

Keywords Modes of public transport · Energy efficiency · Fuel consumption · Emissions · Public transport mode capacity

\section{Introduction}

Megacities all over the world are experiencing rapid growth of motorized transportation [1, 2]. Karachi is one of the megacities that face severe transportation problems $[3,4]$. The situation is deteriorating day-by-day due to a lack of appropriate transport policies and decision making. The lack of a properly regulated and monitored public transport system results in a gap which is filled by the non-professional private sector. The informal private sector works on the principle of profit maximization, which results in a poor level of service for commuters. In this situation, commuters experience problems in comfort, availability, accessibility, and safety which trigger commuters to switch to either private vehicles or paratransit/e-hiring services. The lack of a proper public transport system resulted in increased dependency on motorbikes and cars $[5,6]$ which contributes to more traffic congestion $[7,8]$. The number of motorbikes registered in Karachi has increased by $50 \%$ during a period of four years from 2013 to 2017, whereas the number of cars has increased by $38 \%$ during the same period [9]. Public transit routes are decreasing continuously, which dropped to 90 routes in 2017 in comparison with 149 routes in 2012 [10].

The informal public transport system in Karachi comprises of various modes, which includes minibus, bus, and chingchi as shown in Fig. 1. The routes for buses and minibuses are approved by the Regional Transport Authority

Afzal Ahmed, afzalahmed@neduet.edu.pk; Syed Muhammad Noman, syednoman@neduet.edu.pk; Mir Shabbar Ali, mshabbar@neduet.edu.pk | 'Department of Civil Engineering, NED University of Engineering \& Technology, University Road, Karachi, Pakistan. ${ }^{2}$ Department of Urban \& Infrastructure Engineering, NED University of Engineering \& Technology, University Road, Karachi, Pakistan. 


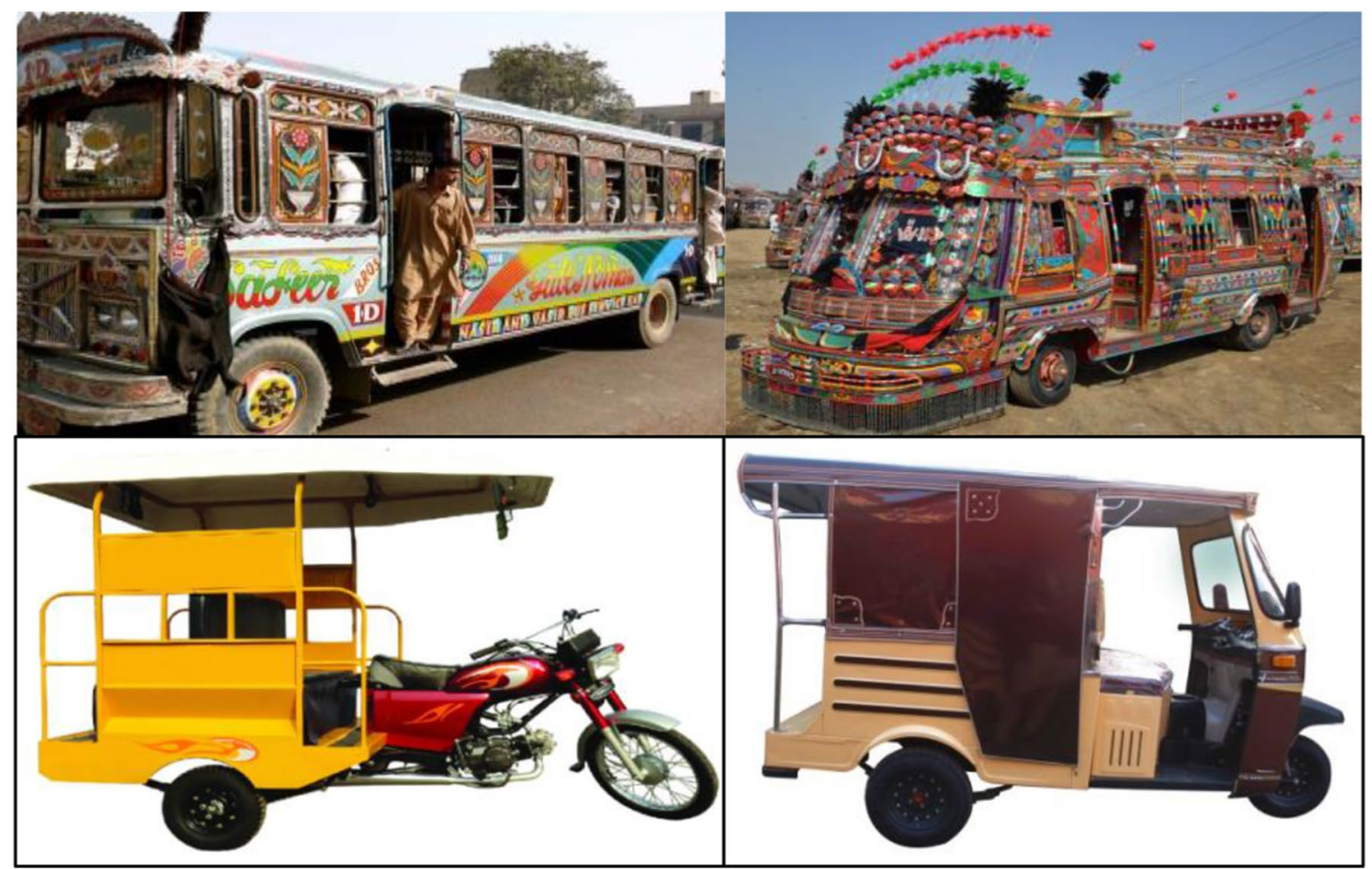

Fig. 1 Public Transport Modes in Karachi: Bus (left top), Minibus (right top), Chingchi Bike (left bottom) and Chingchi Rickshaw (right bottom)

Table 1 Type of public transport modes available and their fuel type

\begin{tabular}{ll}
\hline \multicolumn{2}{l}{ Public transport modes } \\
\hline Type & Fuel \\
\hline Bus & CNG \\
Minibus & CNG \\
Minibus & Diesel \\
Chingchi bike & Petrol \\
Chingchi Rickshaw & CNG \\
\hline
\end{tabular}

(RTA), whereas chingchi, which carries a significant number of public transport commuters, operates without approved service routes. These modes have distinct characteristics related to capacity, fare, operational cost, and type of fuel used by the vehicle. At present, three different fuels are used by public transport, which includes petrol, diesel and Compressed Natural Gas (CNG). Different types of fuels used by public modes of transportation are given in Table 1. Almost all the buses and minibuses were diesel operated until 2005 [11]. The significant difference between fuel cost on CNG and diesel encouraged the operators of buses and minibuses to transform the engines of buses to CNG engines, which resulted in minibuses operating on two different fuels (diesel or CNG) and all the buses converted to CNG-based engines.

Chingchi, a low-capacity three-wheeler public transport service, has now become an integral component of the public transport network in Karachi. Two different types of chingchis are operated, which include CNG rickshaw converted chingchi and petrol operated motorbike converted chingchi. Currently, chingchi operates on shorter routes comprising of collectors and minor arterials. The operation of chingchi on most of the major arterials is prohibited by the authorities.

In developing countries, most of the energy demand is derived from petroleum and fossil fuel-based products [12] for decades [13]. The transportation sector of Pakistan is the major consumer of fossil fuel. In Pakistan, almost $56 \%$ of petroleum products were used in the transportation sector during 2016-2017. The consumption of petroleum products in transportation is increasing at a rate of $9.8 \%$ per year [14], which also affects the growth of associated sectors of the economy [15]. The increase in petroleum consumption leads to the expenditure of more foreign exchange in the import of petroleum products, which negatively impacts the already struggling economy. On the contrary, developed country such as the USA spends $29 \%$ of its total energy in the transportation sector, whereas $55 \%$ of total energy demand is derived from petroleum-based products in the US [16]. The transportation sector of the European Union (EU) countries consumes $42 \%$ of total energy in which the share of renewable energy was $17 \%$ in $2016[17,18]$. The energy consumption in the transport sector leads to greenhouse gas emissions.

\section{SN Applied Sciences}


Globally almost one-quarter of the total greenhouse gas emissions are contributed by the transport sector [19]. In the US, transport sector generates about $29 \%$ of the total $\mathrm{CO}_{2}$ emissions. The transport sector in Ontario, Canada accounts for $20 \%$ of the overall $\mathrm{CO}_{2}$ emissions, whereas $27 \%$ of total $\mathrm{CO}_{2}$ emission in the $\mathrm{EU}$ is generated from the transport sector [20-22].

Increasing environmental concern contributes to making the transportation system more fuel-efficient. Vehicular emissions are one of the major negative traits of the transportation process [23]. Continuous efforts have been made to reduce vehicular emissions by improving vehicular technologies, such as replacement of fossil fuel-powered based bus fleet with the electric buses [24]. Various models have been proposed to optimize the demand for fuel in the transportation sector by encouraging public transport and using energy-efficient buses. Yasmeen et al. highlighted the need for upgrading the existing energy consumption structure in Pakistan to a more sustainable structure to reduce $\mathrm{CO}_{2}$ emissions [25]. A fuel consumption model was developed to reduce the emissions for bus operation while pubic transport serving on main routes of the network [26]. Similarly, several analytical and linear models have been proposed to estimate the fuel consumption and efficiency of different operations in the vehicle, such as acceleration, cruising at a constant speed and Advance Driving Assistance System (ADAS) in different modes of transport [27, 28].

Increased efficiency in fuel consumption and a more environment-friendly transport sector can be achieved by using alternative fuel and electric-powered vehicles which are less harmful to the environment [24]. Extensive efforts have been made in analysing the use of different fuel on the bases of various parameters, such as lifecycle cost, operation cost, and maintenance cost of different engine types [29]. Comprehensive cost-benefit analysis of public transport buses was performed to analyze the advantages and disadvantages of different fuels in buses [30-32]. Exhaustive multi-criteria analysis on advance fuel options, such as electricity, methanol, and hydrogen fuel cell in hybrid electric buses was performed which shows that electricity is the best alternative for the buses in the study area with less emission in comparison with other fuel options [33]. Vehicular emissions and energy consumption are driving factors in transforming the existing transport system to the sustainable transport system, which is being achieved in developed countries by converting the existing fleet into electric vehicles and by changing fuels to CNG or Bio-Fuel in developing countries.

In addition to energy and emissions, the capacity of the public transport mode is also important in the selection of a public transport mode for a city. Different modes of public transport have different capacities and Passenger-Car
Equivalent (PCE) factors. The value of PCE is an indicator of road capacity utilization for the given mode. Preference should be given to the mode of transport with the highest value of passenger carrying capacity per PassengerCar Unit (PCU). A study in Dhaka, Bangladesh concluded that commuters prefer the mode of public transport with a higher capacity [34]. Another study performed in Dublin, Ireland compared the stress among commuters of two different tram routes with different capacities and passenger load. The research concluded that the stress level is affected by the passenger load to the capacity ratio of the tram route [35]. The transit capacity of a route is also an important factor to make the public transport successful, as highlighted in the study of Santiago bus-based transit system [36]. Furthermore, the higher capacity mass transit system is highly feasible to the cities having high-density population $[37,38]$.

The existing literature on public transport provides the comparison of PT and car users [39], analysis on BRTS (Bus rapid transit system) and MRTS (Mass rapid transit system) [40], and also the comparison of advance mobility services like PRT (Personal rapid transit), e-bikes (electric bicycles) with BRT and LRT (Light rail transit) [41]. However, the existing literature lacks in detailed performance evaluation of chingchi as a mode of public transport. Therefore, the contributions of the present study are listed below:

- This study performs a detailed evaluation of chingchi as a mode of public transport and compares its performance with other modes:

- This study evaluates the major performance indicators such as energy consumption, emissions, and capacity of public transport of a megacity in a developing country.

The results of this study are useful in the evaluation of public transport modes, which should be given due consideration in the planning and operations of the transport system of a city.

\section{Methodology and data collection}

Karachi is the economic hub and most populous city of Pakistan with an area of $3,780 \mathrm{~km}^{2}$ [42]. According to the census conducted in the year 2017, the population of Karachi city was 16.62 million [43]. According to the Regional Transport Authority, Sindh, the existing public transport network of Karachi consists of 12 routes of buses and 59 routes of minibuses [44]. The data on existing routes of chingchi is not available, as chingchi operates without officially approved routes. 
Two types of surveys were performed in this research to collect the data required to compare the selected parameters of available modes of public transport in Karachi.

\subsection{Questionnaire-based survey}

The data about the average fuel consumption, route lengths, frequencies, passenger capacity, and operation cost were collected by conducting surveys from drivers and operators of buses and chingchi. The number of samples for each mode of public transport is shown in Table 2. In total, the opinion of 102 experienced drivers was collected through the questionnaire. The questionnaire survey included the question on the following parameters:

- Length of route

- Type of fuel

- Fuel capacity

- Number of completed trips per day

- Frequency during peak-hour and off peak-hour

- The average number of passengers served per trip

- Fuel consumption per trip

The data acquired from the questionnaire survey was used to analyse the trend of route length for different modes of public transport. The average fuel consumption per kilometre and average fuel consumption per passenger-km are based on the data acquired from the survey. The average fuel consumption data forms the basis of estimating average fuel cost and emissions for different public transport modes.

\subsection{Route survey}

Route survey was performed on the selected routes of public transport to estimate the number of passengers boarding and alighting at different bus-stops, and travel time of the selected mode. Three observations were made on each of the surveyed routes of a specific mode of public transport. The data was collected in peak hours of working days to capture the average trend of commuting. This data was needed to estimate average passenger load, as the analysis is performed per passenger units.

The surveys were performed in December 2018. The fuel prices used in the analysis for comparison were also based on the fuel prices at the time of the survey, although there has been a fluctuation in prices since then.

\section{Data analysis and results}

\subsection{Comparison of capacity and trip length}

In public transport, the mode capacity and route/trip length are the most important parameters to make it valuable for the planners and commuters. The frequency of buses is increased during peak-hour and buses with higher capacity such as articulated or bi-articulated buses are operated during peak hours. Similarly, during off-peak hours buses with low capacities are operated at a lower frequency to meet the demand to ensure optimal operation of the public transport system. However, in Karachi, the public transport modes (bus/chingchi) with fixed capacity are operated. The operators of public transport routes adjust the frequency of the bus/chingchi to meet the fluctuating demand. It is also observed that the operators purposely keep the frequency lower than the demand to ensure maximum profit, as there is no framework in place to ensure a certain level-of-service. Another important parameter associated with the mode of public transport is its $P C E$, especially when it operates in mixed traffic. Table 3 shows the capacities and PCE factors of the available modes of public transport in Karachi.

Table 3 shows that the capacity of bus service is highest among the existing modes of public transport, which is relatively higher as compared to other public transport, which are 75 persons per bus. Whereas, the capacity of a minibus is 40 persons and petrol operated bike-chingchi has the sitting capacity of 8 persons per vehicle.

The mode of public transport with the highest value of passengers per PCU should be preferred, as it is an
Table 2 Sample size for data collection

\begin{tabular}{lllclc}
\hline Type of public transport & Fuel & Number of routes & $\begin{array}{l}\text { Sur- } \\
\text { veyed } \\
\text { routes }\end{array}$ & $\begin{array}{l}\text { Observations } \\
\text { for route } \\
\text { survey }\end{array}$ & $\begin{array}{l}\text { Sample for } \\
\text { questionnaire-based } \\
\text { survey }\end{array}$ \\
\hline Bus & CNG & 12 & 5 & 15 & 15 \\
Minibus & CNG & 59 & 10 & 30 & 40 \\
Minibus & Diesel & 3 & 9 & 11 \\
Chingchi-bike & Petrol & Unknown & 3 & 9 & 12 \\
Chingchi-Rickshaw & CNG & Unknown & 5 & 15 & 24 \\
Total & & & 28 & 78 & 102 \\
\hline
\end{tabular}


Table 3 Capacities and PCE factors of public transport modes

\begin{tabular}{lll}
\hline Type & $\begin{array}{l}\text { Capacity (sit- } \\
\text { ting + standing) }\end{array}$ & PCE factor [54] \\
\hline Bus & 60 & 2.5 \\
Minibus & 40 & 2 \\
Chingchi bike & 8 & 0.5 \\
Chingchi rickshaw & 8 & 0.5
\end{tabular}

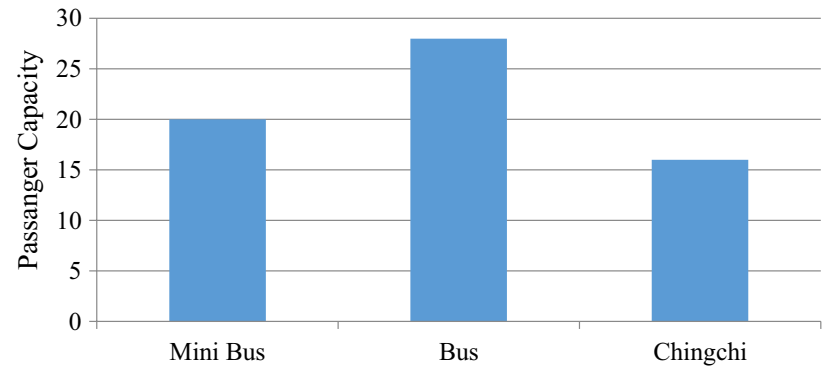

Fig. 2 Passenger capacity per PCU for different modes of public transport

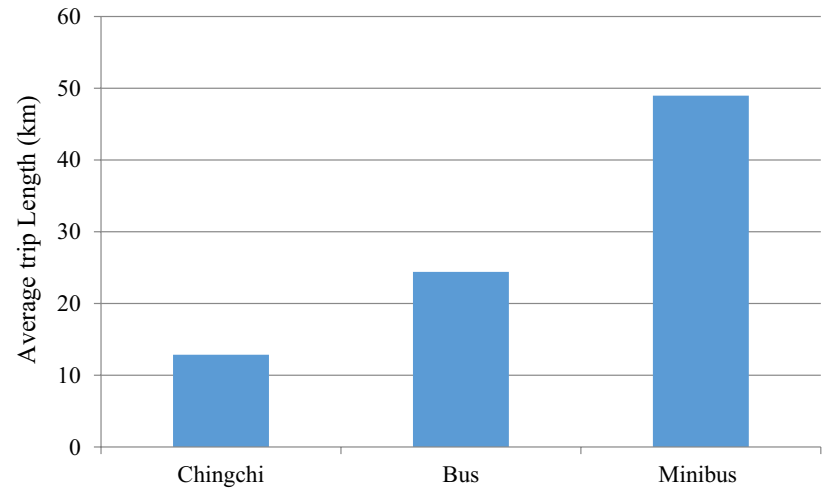

Fig. 3 Average trip lengths of public transport modes

indicator of optimal road space utilization. Figure $2 \mathrm{com}-$ pares the values of passengers per PCU for different modes of public transport and it indicates that the bus has the highest number of passengers per PCU with 28 passengers per PCU. Chingchi has the least values of passengers per PCU, which is 16 passengers/PCU. The higher value of passenger per PCU also highlights the significance of having a proper public transport system, where more persons can be accommodated in less space in comparison with private modes of transport. Furthermore, this analysis also suggests that bus or any other mode with higher capacity should be used in urban public transport.

The data of route lengths for the selected routes were collected and the average route length is shown in Fig. 3. Chingchi is operated without approved routes and its

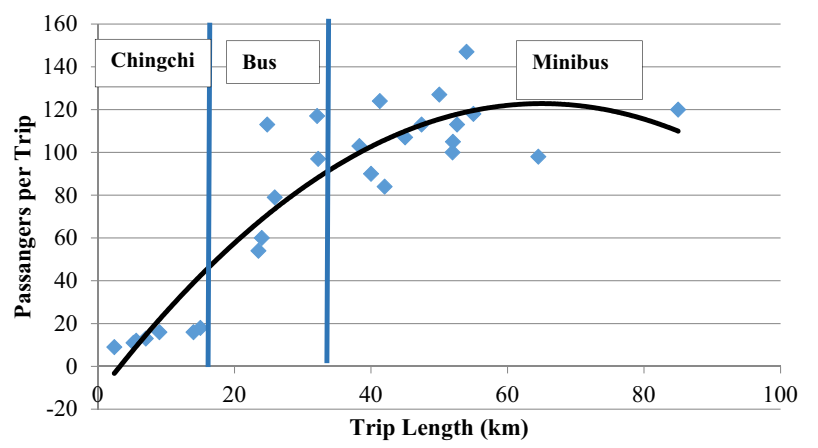

Fig. 4 Relationship between passenger per trip and trip length

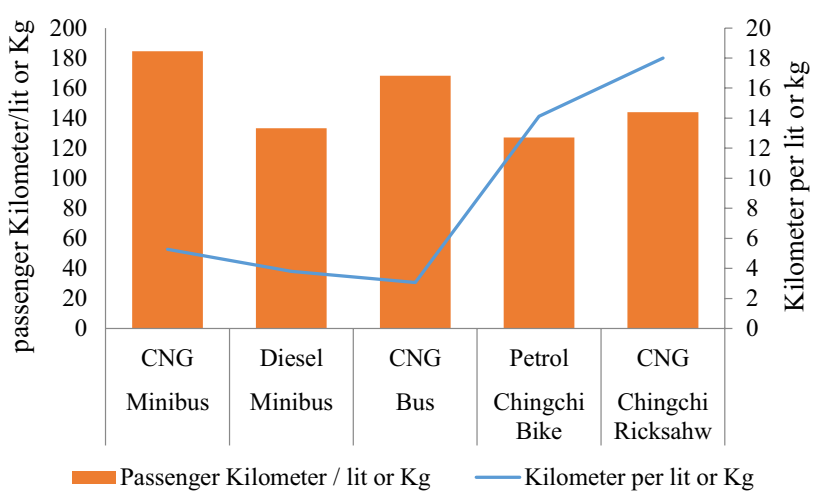

Fig. 5 Kilometre per litter and Passenger kilometre per lit or kg

operation on some major arterials is prohibited. Therefore, it operates mainly on collector roads with shorter routes. Thus, chingchi has the least observed route length with $12.87 \mathrm{~km}$, whereas minibuses have the longest routes with around $49 \mathrm{~km}$ route length. Figure 4 shows the number of passengers served during a trip by different public transport modes. It indicates that, as expected, the number of passengers increases with the increase in trip length. Therefore, longer public transport routes are better for the transport system.

\subsection{Comparison of fuel consumption and cost}

The categories of PT modes for fuel analysis are more than the categories of PT modes used in previous sections, as minibuses and chingchi are operated on two different fuels. Bus and chingchi rickshaw only use CNG as fuel, chingchi bike uses petrol, and minibuses are operated on both CNG and Diesel. Fuel consumption for different modes on different fuel types is based on the survey data collected from drivers and operators of these modes. Estimated mileages in kilometre per unit of fuel are compared in Fig. 5 along with passenger kilometre per unit of fuel. Fuel consumption for petrol and diesel is measured in 
litters and CNG is measured in kilograms. Figure 6 compares the cost per unit distance and cost per passenger kilometre for available modes of PT in Karachi.

The comparison shown in Fig. 5 reveals that CNG buses consume the highest amount of fuel to travel a unit distance in comparison with other modes. The most fuel-efficient mode of PT is chingchi rickshaw which gives highest $\mathrm{km}$ per $\mathrm{kg}$ of CNG i.e. $18 \mathrm{~km}$ per kg. In terms of fuel efficiency measured in passenger-km per unit fuel, the most efficient PT mode is CNG minibus, whereas the least fuelefficient mode is petrol chingchi bike.

Figure 6 shows that per kilometre cost of travel is highest for CNG bus and lowest for CNG chingchi rickshaw. However, travel cost per passenger kilometre is lowest for CNG minibus with PKR 0.56 Rs/passenger-km, and highest cost is estimated for a diesel-fuelled minibus with $0.81 \mathrm{Rs} /$ passenger $/ \mathrm{km}$. This shows that for similar types of minibuses, the change of engine from diesel to CNG reduces the fuel cost for transportation by $30 \%$. The cost for all other modes exists within this range.

Statistical analyses of the collected data were performed to determine if there is a significant relationship between fuel consumption and the type of PT mode. The outcome of one-way ANOVA analysis is shown in Table 4. The null hypothesis assumed that there is no association between fuel consumption/cost and the mode of PT. The results show that $p$ value for one-way ANOVA between mode of transport and cost of fuel per km and cost of fuel per passenger kilometre is less than 0.001 , which means that null hypothesis is rejected and alternate hypothesis is accepted. Thus, it can be concluded that there is a significant association between different modes of public transport and their cost of travel.

\subsection{Comparison of energy consumption}

The comparison for fuel consumed by different modes of PT is discussed in the previous section. Fuel consumption

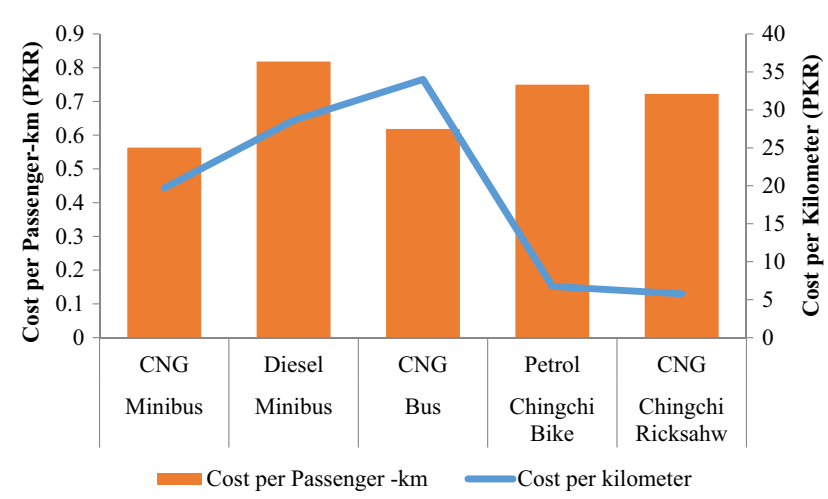

Fig. 6 Cost per km and Cost per passenger-km
Table 4 Statistical analysis of cost parameter with available PT modes

\begin{tabular}{llrl}
\hline & $\begin{array}{l}\text { Degree of } \\
\text { freedom }\end{array}$ & F value & P value \\
\hline Cost of fuel per km & 4 & 334.902 & 0.000 \\
$\begin{array}{l}\text { Cost of fuel per passen- } \\
\text { ger per km }\end{array}$ & 4 & 28.163 & 0.000 \\
\hline
\end{tabular}

and energy consumption may be different, as the amount of energy produced by the combustion of the unit amount of different fuels may be different. Furthermore, the fuels in existing modes of PT are measured in different units, whereas the unit of energy consumption for all the fuels will be the same. The energy consumed in transporting a unit distance per person is estimated by multiplying the amount of fuel consumed per km per person with the energy produced by combustion of that fuel type. The data of the amount of fuel consumed per km per person was acquired in the survey from transport operators, which is presented in Fig. 5. The amount of energy produced by unit fuel combustion is taken from the available literature [45].

The comparison of energy consumption shows that the PT modes using high octane fuel are utilizing higher energy. Fuel types like diesel and petrol have higher energy contents in comparison with CNG measured in British Thermal Unit (BTU) [46]. Figure 7 compares the energy computation for different modes of PT. It shows that the diesel-driven bus consumes the highest amount of energy per passenger-km. There is a significant difference in the amount of energy consumed by CNG-powered engines and petrol/diesel driven engines. CNG minibus has the least value of energy consumption, which is 8.9 BTU per passenger kilometre in comparison with 275.9 BTU per passenger kilometre for diesel minibus.

Statistical analysis of energy consumption per kilometre and per passenger kilometre, represented in BTU, shows

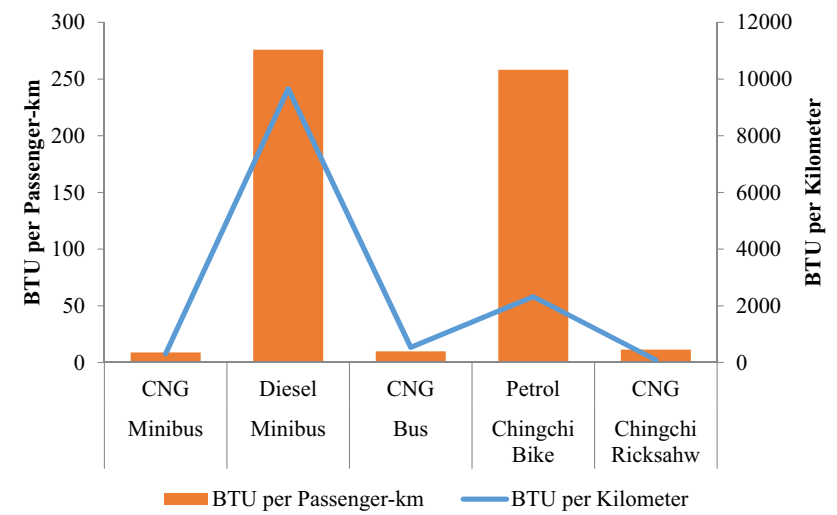

Fig. 7 Energy consumption per km and per passenger-km in BTU 
that there is a significant association between modes of PT and energy consumption. The results of the one-way ANOVA are shown in Table 5. The P value for BTU per kilometre and BTU per passenger-km is less than 0.001 , which shows that the alternate hypothesis may be accepted, indicating that there is an association between energy consumption and mode of PT.

\subsection{Comparison of emission}

The emissions from the transport sector are a major contributor to overall carbon-footprint. The emissions resulting from transport of persons can be reduced by increasing the share of public transport and reducing the dependency on private vehicles. Within various modes of public transport, the emissions are dependent on capacity and engine type of mode. This research also compares the emissions by different modes of PT in Karachi.

Actual emissions from a specific model can be accurately estimated using tailpipe emission analysis. Calibrated models exist for tailpipe emissions for different types of vehicles. However, there is no such data for the local modes of transport used in Karachi, as the emissions are affected by the type, age, maintenance and various operational parameters [47]. Due to lack of existing emission factors for local transport modes, this study estimates the emissions based on the fuel/energy consumption data collected from the survey along with standard values of emissions per unit consumption of energy [48].

The comparison of emissions for different modes of transport measured in the equivalent of $\mathrm{CO}_{2}$ is shown in Fig. 8. Figure 8 shows a trend similar to the trend observed in Fig. 7. The emissions are directly dependant on the amount of energy produced during the combustion process. Results show that the highest emissions per passenger kilometre for travelling a unit distance are highest for the diesel-powered minibus. Similarly, CNG minibus emits the least $\mathrm{CO}_{2}$ during transport of passengers.

The amount of emissions per passenger per $\mathrm{km}$ is higher in diesel and petrol-driven PT modes as compared to CNG-driven PT modes. Results show that two types of minibuses with the same transportation capacity but different fuels (diesel and CNG) have significantly different emissions. Figure 8 shows that diesel minibus emits

Table 5 Statistical analysis of energy consumption by different modes of PT

\begin{tabular}{llrr}
\hline & $\begin{array}{l}\text { Degree of free- } \\
\text { dom }\end{array}$ & F value & P value \\
\hline BTU per km & 4 & 863.598 & 0.000 \\
$\begin{array}{l}\text { BTU per passenger } \\
\text { per km }\end{array}$ & 4 & 1115.861 & 0.000 \\
\hline
\end{tabular}

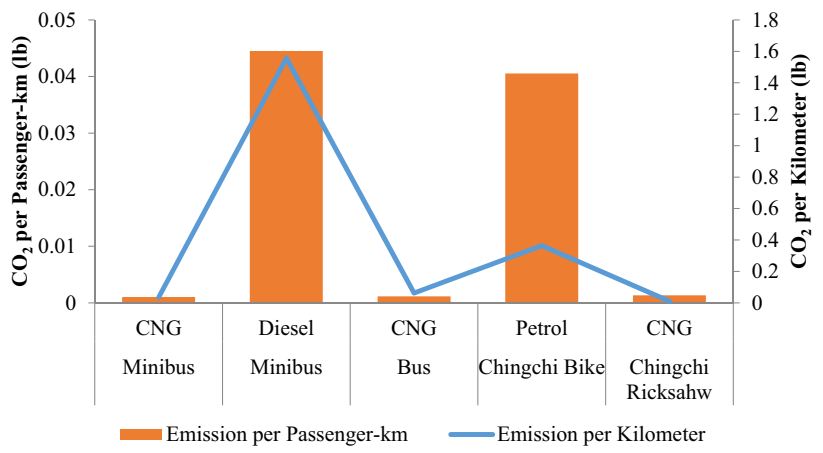

Fig. 8 Emission per km and per passenger-km

$1.557 \mathrm{lb}$ of $\mathrm{CO}_{2}$ per $\mathrm{km}$, whereas CNG minibus emits $0.0364 \mathrm{lb}$ of $\mathrm{CO}_{2}$ per $\mathrm{km}$, which is around 42 times. Statistical analysis of emission per kilometre and emission per passenger-km shows a significant association between PT modes and emissions from various available modes, as indicated by results of one-way ANOVA shown in Table 6 .

\subsection{Introduction and comparison of BRT system}

The existing public transport system in Karachi is dominated by poorly operated and informal modes. The public transport operates without enforcement of any level of service criteria (time headways, punctuality, and seat/ space availability) by the authorities. No bus schedules exist for any mode and route of public transport in Karachi and the entire public transport is operated on the principle of profit maximization by their operators. This results in continuously decreasing dependency on PT and more reliance on private vehicles, which leads to unsustainable transport system [9].

Finally, authorities have realized the significance of having a proper mass transit system and five Bus Rapid Transit (BRT) routes, as suggested by JICA Japan International Cooperation Agency, are being introduced in Karachi. The routes have been named as Green Line, Orange Line, Red Line, Blue Line, and Aqua Line. The infrastructure for Green Line and Orange Line BRT routes is under construction, while the other three BRT lines are in the planning phase. Green Line has a $25 \mathrm{~km}$ long dedicated bus-corridor with right of way category A. This section compares the BRT

Table 6 Statistical analysis of energy consumption per $\mathrm{Km}$ with available PT modes

\begin{tabular}{llrl}
\hline & $\begin{array}{l}\text { Degree of } \\
\text { freedom }\end{array}$ & F value & P value \\
\hline Emission per km & 4 & 880.12 & 0.000 \\
$\begin{array}{l}\text { Emission per passen- } \\
\text { ger per km }\end{array}$ & 4 & 1126.82 & 0.000 \\
\hline
\end{tabular}


buses with the existing modes of PT to highlight the significance of the proposed mass transit system.

According to the official document, the fleet of buses for Green Line BRT will comprise of diesel-powered articulated buses with seating plus the standing capacity of 150 persons/bus $[49,50]$. This research compares the attributes of the proposed diesel-powered bus with the existing modes of public transport. A CNG-powered articulated bus with similar capacity is also included in the analysis to compare the improvement in various operational parameters if a CNG operated bus would have been used instead of a diesel-driven bus.

The comparison of existing modes of PT with BRT is compared in Fig. 9. It shows that the BRT has a capacity of carrying 50 passengers per $P C U$, which is approximately twice the capacity of a bus. Thus, more passengers can be transported in comparatively lesser space with the introduction of BRT.

The data about the fuel consumption of the existing modes of PT was collected using the field survey. The fuel consumption of the proposed diesel bus is based on the data available from the official report $[49,50]$. For comparative analysis, a CNG bus with similar capacity is selected. Figure 10 shows that passenger-km per litre of

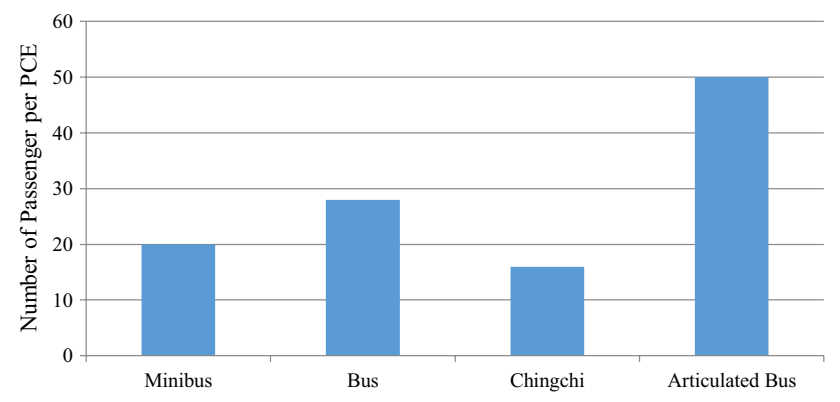

Fig. 9 Comparison of BRT passenger carrying capacity with existing PT modes fuel is comparatively higher for diesel articulated bus than the CNG articulated bus. The passenger-km per litter for diesel articulated bus is 320, whereas for diesel minibus 133 passengers are transported per litre of diesel. Similarly, passenger-km per litter for CNG articulated bus is significantly higher than CNG minibus. This shows that a significant amount of fuel can be saved by the introduction of BRT and replacing the existing PT routes with articulated buses.

The fuel cost per $\mathrm{km}$ of travel and fuel cost per passenger kilometre is compared in Fig. 11. It shows that the fuel cost per passenger-km is lowest for diesel articulated bus, which is PKR 0.346 PKR per passenger-km, whereas the fuel cost for CNG articulated bus is 0.39 PKR per passenger$\mathrm{km}$. This could be the main reason behind the selection of diesel buses for Green Line BRT route. Furthermore, the supply of CNG is not consistent, as it suffers from a shortage of supply and closure on certain weekdays to manage the demand. However, using CNG is significantly environmental friendly. Figure 12 compares the energy consumed per passenger-km of BRT with the existing PT modes. The amount of energy consumed by diesel articulated bus is around seven times higher than the CNG articulated bus. The energy consumed per passenger-km for diesel articulated bus is significantly lower than current PT modes on diesel and petrol. Similarly, the $\mathrm{CO}_{2}$ emission per passenger-km is significantly lower for CNG articulated bus in comparison with diesel articulated bus.

The comparison of $\mathrm{CO}_{2}$ emissions from existing public transport modes and the proposed articulated buses for Green Line BRT is shown in Fig. 13. All the CNG fuelled modes have significantly lower emissions in comparison with petrol and diesel-fuelled modes. Furthermore, the diesel-fuelled articulated bus has less than half $\mathrm{CO}_{2}$ emissions per passenger-km in comparison with the diesel operated minibus. The comparison of the proposed diesel-fuelled articulated bus with the assumes CNG articulated bus shows that the emissions from CNG
Fig. 10 Comparison of fuel consumption of BRT with existing modes of PT

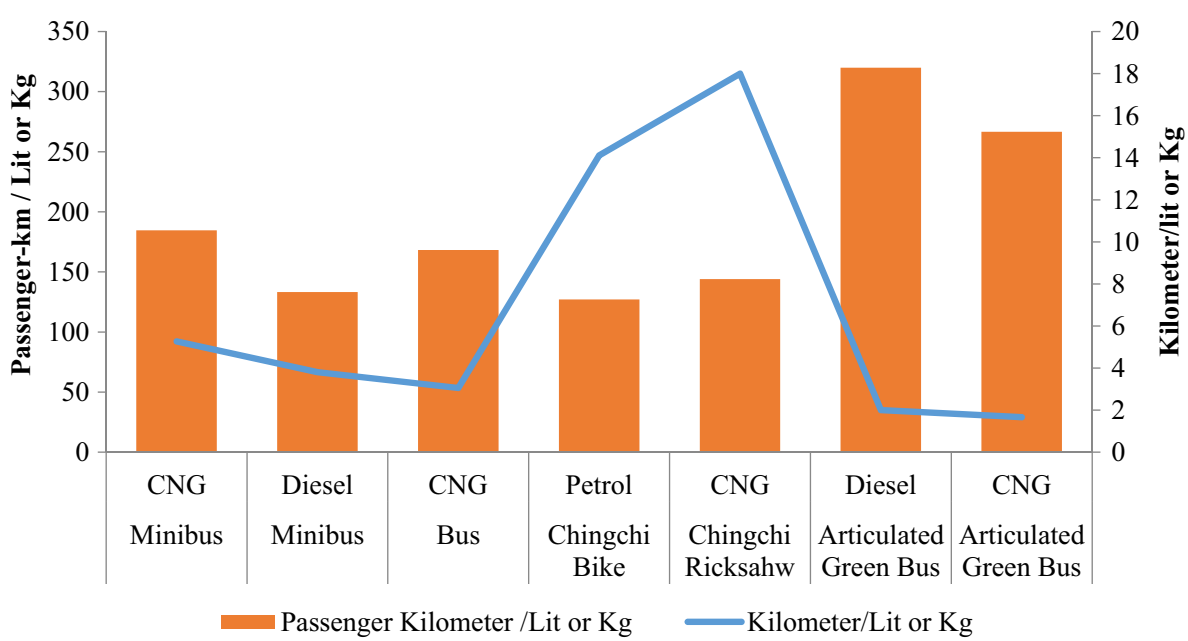


Fig. 11 Comparison of fuel cost of BRT with existing modes of PT
Fig. 12 Comparison of energy ing modes of PT consumption of BRT with exist-
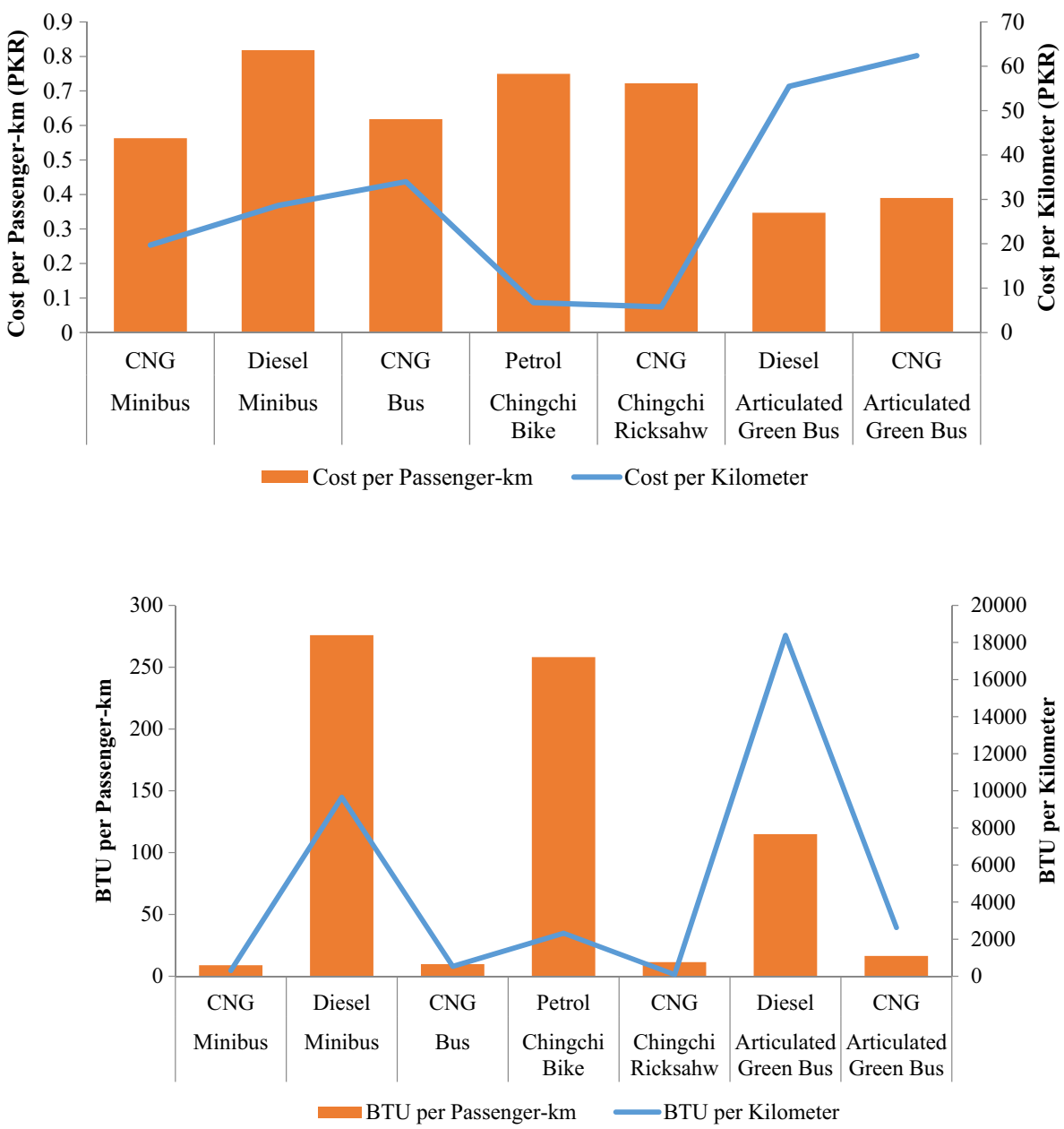

Fig. 13 Comparison of $\mathrm{CO}_{2}$ emissions of BRT with existing modes of PT

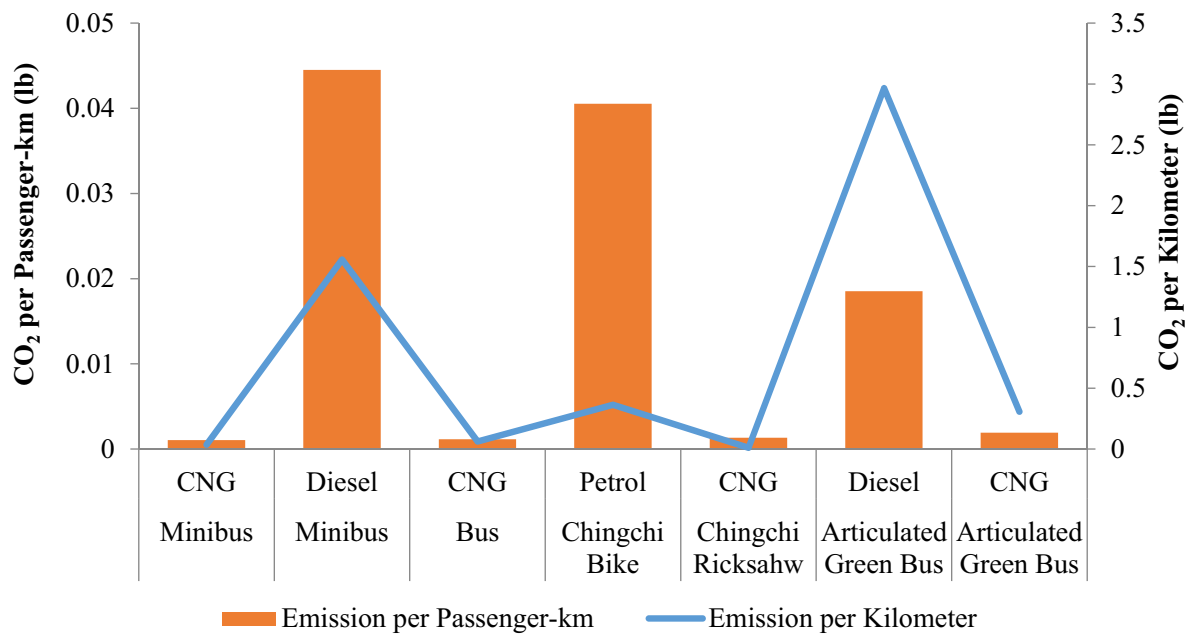

articulated bus are approximately ten times less than the diesel-fuelled articulated bus. This shows that emissions from CNG fuelled articulated buses are significantly lower and the environmental impact of Green Line BRT can be reduced by considering CNG fuelled buses. 


\section{Discussion}

The various attributes of public transport modes available in Karachi are compared in the previous section. All the existing public transport in Karachi is operated by the private operators without any subsidies and intervention by the transport authorities. This results in a suboptimal transport system which causes more fuel consumption and emissions.

The existing literature in the evaluation of public transport modes lacks in the comparative analysis of informal modes such as minibuses and chingchi. Furthermore, the studies on CNG operated public transport modes also lack in the existing literature. This study for the first time evaluates the performance of informal modes. The summary of all the estimated parameters for available public transport modes in Karachi is shown in Table 7.

Public transport substantially reduces emission and energy consumption in comparison with private transportation. A study in the US concluded that a passenger car with one person may yield 10.62 passenger$\mathrm{km}$ per lit, whereas public transport can produce 69.3 passenger-km [51]. Another comparative study in the US compared the energy and emissions efficiency of various private and public modes of transport, which shows that in the US, the efficiency of transit buses is measured at 15 passenger-km per litter [52]. Whereas, the estimated passenger-km per unit of fuel ( $\mathrm{kg}$ of CNG) is 168 , which is more than ten times the reported value from the US. For minibus, 133 passenger-km per litre of diesel is estimated, which is around nine times higher than the reported value of the US. This significantly higher number shows that public transport buses are operated at capacity or overloaded, as the operators of these modes want to maximize their profit. The public transport operators adjust the departure frequency of buses so that the profit of buses is maximized at the cost of reliability of public transport.

The comparison of $\mathrm{CO}_{2}$ emissions from public transport modes of Karachi is compared with reported values of emissions from other cities including Pune (India), Mexico City (Mexico), and Shanghai (China) in Table 8 [53]. Among the above-mentioned cities, three-wheeler public transport is only found in Pune, India, which is mostly operated on Liquid Petroleum Gas (LPG). Furthermore, the values for CNG operated public transport modes for these cities are also non-existent. The comparison of Karachi and Pune shows that LPG operated threewheeler in Pune produces less $\mathrm{CO}_{2}$ per $\mathrm{km}$ than petrol operated chingchi in Karachi. Whereas, the CNG operated chingchi in Karachi is more environmental friendly
Table 7 Comparison of available public transport modes in Karachi

Table 8 Comparison of emission results of this study with other cities

\begin{tabular}{lllll}
\hline Modes & \multicolumn{2}{l}{ Karachi, Pakistan (This study) } \\
\cline { 2 - 5 } & Pass-km/L & BTU/pass-km & CO $_{2}(\mathrm{lb}) /$ pass-km & Pass/PCU \\
\hline Bus (CNG) & 168.185 & 9.768 & 0.001143 & 20 \\
Minibus (diesel) & 133.276 & 275.9 & 0.44 & 28 \\
Minibus (CNG) & 184.58 & 8.9 & 0.00104 & 28 \\
BRT/articulated bus (diesel) & 320 & 114.91 & 0.0185 & 50 \\
BRT/articulated bus (CNG) & 266.67 & 16 & 0.00192 & 50 \\
Chingchi (petrol) & 127 & 258.18 & 0.041 & 16 \\
Chingchi (CNGl) & 144 & 11.40 & 0.00134 & 16 \\
\hline
\end{tabular}

\begin{tabular}{|c|c|c|c|c|c|}
\hline \multirow[t]{2}{*}{ Type of vehicle } & \multicolumn{5}{|c|}{$\mathrm{CO}_{2}$ pound per vehicle-kilometre } \\
\hline & \multicolumn{2}{|c|}{ Karachi (This study) } & \multirow{2}{*}{$\begin{array}{l}\text { Pune India [53] } \\
0.097\end{array}$} & \multirow{2}{*}{$\frac{\text { Mexico [53] }}{0.1478}$} & \multirow{2}{*}{$\begin{array}{l}\text { Shanghai }[53] \\
0.156\end{array}$} \\
\hline Two wheeler & Petrol & - & & & \\
\hline \multirow[t]{2}{*}{ Three wheeler } & Petrol & 0.3648 & 0.1565 & - & - \\
\hline & CNG & 0.106 & & - & - \\
\hline \multirow[t]{2}{*}{ Bus } & CNG & 0.063 & - & - & - \\
\hline & Diesel & - & 2.839 & 1.763 & 2.234 \\
\hline \multirow[t]{2}{*}{ Minibus } & CNG & 0.036 & - & - & - \\
\hline & Diesel & 1.56 & - & - & - \\
\hline \multirow[t]{2}{*}{ Articulated/BRT bus } & CNG & 0.307 & - & & - \\
\hline & Diesel & 2.965 & - & & - \\
\hline Car & Petrol & - & 0.77 & 0.832 & 0.91 \\
\hline
\end{tabular}


in comparison with LPG operated three-wheeler in Pune. It is also evident from Table 8 that CNG operated buses in Pakistan produce 45 times lesser $\mathrm{CO}_{2}$ in comparison with diesel operated buses in Pune.

\section{Conclusions and recommendations}

This study provides a detailed comparative analysis of existing modes of public transport in Karachi. The existing public transport system of Karachi is poorly regulated and operated by the private sector without any subsidies and checks on service parameters. The poor service of public transport results in commuters shifting to private transport modes, resulting in less demand for public transport. This decrease in demand causes further depreciation in the service of public transport and this vicious goes on. A recent shift in policy to introduce a proper mass transit system in the form of BRT is expected to improve the existing situation of transport networks in one of the most populous cities of the world.

A comparative analysis of selected parameters of existing public transport modes in Karachi is presented in this study. The data about operation parameters such as route lengths, average fuel consumption, and operating frequency was collected from the operators of public transport using questionnaire-based survey technique. The data about the average number of passengers for different modes were collected using the route-check method.

The analysis of data shows that buses have the highest number of passengers per PCU among the existing modes of public transport in Karachi. This shows that more persons can be transported in less space with public transport modes of higher capacity. Results show that chingchi has the highest mileage in kilometre per unit fuel among all the existing modes, whereas CNG operated minibus leads in passenger-km per unit fuel. Similarly, the fuel cost per passenger per $\mathrm{km}$ is lowest for CNG operated minibus among the existing modes; whereas diesel operated minibus has the highest cost per passenger per $\mathrm{km}$. The comparison of energy consumption and emissions for the existing modes of public transport shows CNG fuelled public transport consumes less energy and is more environmental friendly in comparison with petrol and diesel operated modes.

This research also evaluates the performance of proposed buses for a $25-\mathrm{km}$ BRT route under construction in Karachi. The diesel-fuelled articulated buses approved by the relevant authorities are compared with the existing modes of public transport in Karachi. A hypothetical scenario is created which assumes CNG buses instead of diesel buses for Green Line BRT. The comparison shows that CNG articulated bus consumes less energy and is significantly less polluting in comparison with dieselfuelled articulated buses. However, the fuel cost of CNG articulated bus is slightly higher than the diesel-fuelled bus. Based on this comparative analysis, it is recommended that CNG buses should be considered for Green Line BRT project in place of the proposed diesel-fuelled articulated buses. The authorities may ensure the continuous supply of the CNG for the BRT buses to make CNG a feasible fuel for the proposed BRT, which is significantly less polluting than the diesel buses.

This study can be used by the authorities to analyse the performance of existing modes and prioritize the PT modes for future planning. The estimation of emissions in this study is based on the fuel consumption data acquired from the operators of various existing modes. However, the actual emissions may vary depending on the type, life, maintenance and driving behaviour of drivers. The estimates of the emissions in this study can be further improved by measuring tail-pipe emissions from various existing public transport modes, which could be an interesting extension of this work.

Acknowledgements This research was carried out with the support of Exascale Open Data Analytics Lab, National Centre in Big Data and Cloud Computing (NCBC), NEDUET, and funded by the Higher Education Commission of Pakistan.

\section{Compliance with ethical standards}

Conflict of interest On behalf of all authors, the corresponding author states that there is no conflict of interest.

Ethical approval Authors confirm that this research survey complies with the ethical standards and it was approved by NED University Ethical Review Committee (ERC). The ERC policy document is available at the following link: https://www.neduet.edu.pk/policies/ EthicalPolicy.pdf. The standards of NED University ERC are in alignment with national and international guidelines. The data has been recorded and analysed anonymously.

\section{References}

1. Mohan D, Tiwari G (2000) Mobility, environment and safety in megacities: dealing with a complex future. IATSS Res 24(1):39-46

2. Balachandra P (2010) Dynamics of urban mobility: a comparative analysis of megacities of India. Indira Gandhi Institute of Development Research, Mumbai

3. Hina Sheikh IN (2017) The six biggest challenges facing Pakistan's urban future. theigc.ogr, Karachi

4. Haq M U (2014) The rise of Karachi as a mega-city (LUMS). https ://mhrc.lums.edu.pk

5. Ahmed A, Ukkusuri SV, Mirza SR, Hassan A (2019) Width-based cell transmission model for heterogeneous and undisciplined traffic streams. Transp Res Record 2673(5):682-692 
6. Ahmed A, Mehdi MR, Ngoduy D, Abbas M (2019) Evaluation of accuracy of advanced traveler information and commuter behavior in a developing country. Travel Behav Soc 15:63-73

7. Ali MS, Adnan M, Noman SM, Baqueri SFA (2014) Estimation of Traffic congestion cost-a case study of a major arterial in Karachi. In: Fourth international symposium on infrastructure engineering in developing countries. Karachi, Pakistan

8. Ahmed A, Mehdi MR, Rizvi SMA, Fatima T (2019) Evaluation of existing performance and potential for optimization of traffic signals in Karachi. Arab J Sci Eng 44(10):8747-8759

9. KCCl (2017) Karachi traffic chaos, jamming the wheels of economy infoanalysis. Karachi Chamber of Commerce Institute, Research and Dvelopment Department, Karachi

10. KMTC (2012) Karachi mass transit program investment oppourtunity. Karachi Metropolitan Corporation, Karachi

11. Qureshi IA, Lu H (2007) Urban transport and sustainable transport strategies: a case study of Karachi, Pakistan. Tsinghua Sci Technol 12(3):309-317

12. Ahuja D, Tatsutani $M$ (2009) Sustainable energy for developing countries. Surv Perspect Integr Environ Soc 2:27

13. Harry J, Barnes G (1991) Energy in developing countries. Energy, Materials, and International Security Division, Washington

14. OCAC (2017) Pakistan oil report. Oil Companies Advisory Council, Islamabad and Karachi

15. Yasmeen $H$, Wang $Y$, Zameer $H$, Solangi YA (2019) Does oil price volatility influence real sector growth? Empirical evidence from Pakistan. Energy Rep 5:688-703

16. EIA (2017) US energy information administration. https://www. eia.gov/energyexplained/?page=us_energy_transportation. Accessed 21 Apr 2019

17. Eurostat Renewable energy (2018) Share of renewable energy in gross final energy consumption, 178 2018. https:// ec.europa.eu/eurostat/tgm/table.do?tab=table\&init=1\&langu age $=$ en\&pcode=t2020_31\&plugin=1. Accessed 15 Aug 2019

18. Eurostat (2019) Final energy consumption by sector and fuel, 17 01 2019. https://www.eea.europa.eu/data-and-maps/indicators /final-energy-consumption-by-sector-9/assessment-4. Accessed 12 Aug 2019

19. McNicol BD, Rand DAJ, Williams KR (2001) Fuel cells for road transportation purpose-yes or no? J Power Sources 100(1):47-59

20. Eurostat transport emission (2019) Greenhouse gas emissions from transport, 12 July 2019. https://www.eea.europa.eu/dataand-maps/indicators/transport-emissions-of-greenhouse-gases /transport-emissions-of-greenhouse-gases-11. Accessed 7 Sept 2019

21. Ottawa CO (2019) Air quality and climate change management plan (AQCCMP), 11 2014. https://ottawa.ca/en/city-hall/plann ing-and-development/official-plan-and-master-plans/air-quali ty-and-climate-change-management-plan-aqccmp. Accessed 5 Sept 2019

22. Hodges $T$ (2010) Public transportation role in responding to climate change. Office of Budget and Policy, Federal Transit Administration U.S. DOT, Washington

23. Sajjad A, Mehdi MR, Noman SM (2019) Comparison of carbon monoxide for metropolitan city at traffic stressed sites-a case study of Karachi 2002-2018. J Mech Continua Math Sci 14(6)

24. Kühne R (2010) Electric buses - an energy efficient urban transportation means. Energy 35(12):4510-4513

25. Yasmeen $H$, Wang $Y$, Zameer $H$, Solangi $Y A$ (2020) Decomposing factors affecting $\mathrm{CO}_{2}$ emissions in Pakistan: insights from LMDI decomposition approach. Environ Sci Pollut Res 27(3):3113-3123

26. Shahriar MK (2002) Fule consumption model for bus rapid transit. J Adv Transp 37(2):139-157
27. Ben-Chaim M, Shmerling E, Kuperman A (2013) Analytic modeling of vehicle fuel consumption. Energies 6(1):117-127

28. Bifulco GN, Galante F, Pariota L, Spena MR (2015) A linear model for the estimation of fule consumption and the impact evaluation of advance driving assistance system. Sustanability 7:14326-14343

29. Lajunen A, Lipman T (2016) Lifecycle cost assessment and carbon dioxide emissions of diesel, natural gas, hybrid electric, fuel cell hybrid and electric transit buses. Energy 106:329-342

30. McKenzie EC, Durango-Cohen PL (2012) Environmental lifecycle assessment of transit buses with alternative fuel technology. Transp Res Part D 17(1):39-47

31. Hellgren J (2007) Life cycle cost analysis of car, a city bus and an intercity bus power train for 2005 and 2020. Energy Policy 35(1):39-49

32. Nurhadi L, Borén S, Ny H (2014) A sensitivity analysis of total cost of ownership for electric public bus. In: 17th Meeting of the EURO Working Group on Transportation, EWGT2014, 2-4 July 2014, Sevilla, Spain

33. Tzeng GH, Lin CW, Opricovic S (2005) Multi-criteria analysis of alternative-fuel buses forpublic transportation. Energy Policy 33(11):1373-1383

34. Andaleeb SS, Haq M, Ahmed RI (2007) Reforming innercitybus transportation in a developing country: a passenger-driven model. J Public Transp 10(1):235-260

35. Cantwell M, Caulfield B, O'Mahony M (2009) Examining the factors that impact public transport commuting satisfaction. $J$ Public Transp 12(2):148-169

36. Fernandez R, Planzer R (2002) On the capacity of bus transit systems. Transp Rev 22(3):267-293

37. TRB (2001) Making transit work: insight from Western Europe. Canada and the United States. Transportation Research Board, National Research Council, National Academy Press, Washington

38. Vuchic V (1999) Transportation for livable cities. Center for Urban Policy Research (CUPR), New Brunswick

39. Fei Y, He M, Liang J (2019) Ideal walking time to transit stops: a comparative analysis between car users and public transit users. In: COTA international conference of transportation professionals. Nanjing, China

40. Ghodmare SD, Bajaj P, Khode BV (2019) Comparative analysis of BRTS and MRTS - an approach required for selection of system. In: Smart technologies for energy, environment and sustainable development. Springer, Singapore, pp 456-477

41. Muller PJ (2019) Some 21st century transportation solutions: a comparative analysis. In: International conference on transportation and development. Alexandria Virginia, United States

42. Sindh Bureau of Statistics (2013) Development statistics of Sindh. Sindh bureau of statistics bureau of statistics complex, Karachi

43. World Population Review (2019) Karachi Population 2019, 5 May 2019. https://worldpopulationreview.com/world-cities/karachipopulation/. Accessed 25 July 2019

44. RTA (2018) Public transport modes evaluation. Regional Transport Authority, Karachi

45. Pelkmans L, De Keukeleere D, Lenaers G (2001) Emissions and fuel consumption of natural gas powered city buses versus diesel buses in real-city traffic. WIT Press, Southampton

46. Demirbas A (2017) Fuel properties of hydrogen, liquefied petroleum gas (LPG), and compressed natural gas (CNG) for transportation. Energy Sources 24(7):601-610

47. Guo H, Sung HM, Dai W, Zhang QY (2004) Development of highresolution motor vehicle emission inventories for city-wide air quality impact analysis in China. Dallas, TX/China: Trinity Consultants Inc/College of Environmental \& Resource Sciences, Zhejiang University, Zhejiang 
48. Khan MI, Yasmin T, Shakoor A (2015) Technical overview of compressed natural gas (CNG) as a transportation fuel. Renew Sustain Energy Rev 51:785-797

49. Pakistan EMC (2015) Environmental impact assessment (EIA) of green line BRT system. EMC Pakistan private limited, Karachi

50. KMC (2012) Transport and mass transit cell, NESPAK. Review of green line route of bus rapid transit, Sindh Mass Transit Cell, Karachi

51. Lowe M, Aytekin B, Gereffi G (2019) Public transit buses: a green choice gets greener, 5 April 2010. https://reason.org/comme ntary/does-bus-transit-reduce-greenhouse/. Accessed 30 Nov 2019

52. Bradley MJ (2007) Comparison of energy use \& CO2 emissions from different transportation modes. American Bus Association, Washington
53. World Bank (2009) South Asia: Shared Views on Development and Climate Change, World bank, 1 January 2009. https://docum ents.worldbank.org/curated/en/789001468294334973/South -Asia-Shared-views-on-development-and-climate-change. Accessed 30 Nov 2019

54. Adnan M (2013) Passenger car equivalent factors in heterogenous traffic environment-are we using the right numbers? In: Fourth international symposium on infrastructure engineering in developing countries, IEDC, pp 106-113, 26-28 Dec 2013.

Publisher's Note Springer Nature remains neutral with regard to jurisdictional claims in published maps and institutional affiliations. 